\title{
PENGARUH KEPEMIMPINAN, BUDAYA ORGANISASI DAN MOTIVASI TERHADAP KINERJA PEGAWAI PADA DINAS SUMBER DAYA AIR, CIPTA KARYA DAN TATA RUANG PROVINSI SUMATERA UTARA
}

\author{
${ }^{1}$ Daksur Poso Alisahbana Hasibuan, ${ }^{2}$ Safrida, ${ }^{3}$ Nusantara Tarigan Silangit, ${ }^{4}$ Ali Asmi Lubis, ${ }^{5}$ Wildan Hidayat \\ $1,2,3,4,5$ Universitas Islam Sumatera Utara \\ Idaksurposo.alisahbana@gmail.com, ${ }^{2}$ safrida1206@ymail.com, ${ }^{3}$ nusantara.trg@gmail.com, ${ }^{4}$ almi.asmi@gmail.com, \\ ${ }^{5}$ wildan.hidayat@gmail.com
}

\begin{abstract}
This research was conducted in Dinas Sumber Daya Air, Cipta Karya dan Tata Ruang Provinsi Sumatera Utara. The population in this study were all employees in each division numbering 187 people with the samples taken just 65 people, the determination of sample collection using random sampling. Instrument or data collection techniques in this study using a multiple choice test that has been in tingakat its validity and reliability. test the classical assumption of normality test, multikolienaritas and heterokedesitas and hypothesis test uses multiple linear regression analysis, $F$ test and $T$ test. Validity of test results obtained rhitung > rtabel for each item reliability test questions and questionnaires obtained a Cronbach alpha of each variable is 0,822 for the variable $X 1,0,864$ for the variable $X 2$ and 0.859 for the variable X3 to 0.922 for the variable $Y$. This value is greater than the level that is significantly r-tabel 0.361. The data analysis of each variable regression equation $Y=15,086+0,400 X 1+0,326 X 2+0,936 X 3+e$. Retrieved $R 2$ of 0.517 , which means the $X 1, X 2$ and $X 3$ explain the effect on variable $Y$ by $51.7 \%$ while the remaining $48.3 \%$ is explained by other variables outside the research. The resulting partial test each independent variables affect the dependent variable with research significance less than 0.05 , and the results of the test-simultaneous calculation of 10.707 with a 3.150 Ftabel which means Fhitung $>F$ table with a level of significant $(\alpha) 0,000<0$, 05, which means that the hypothesis is accepted that Leadership, Organizational Culture and Motivation on Employee Performance at Dinas Sumber Daya Air, Cipta Karya dan Tata Ruang Provinsi Sumatera Utara.
\end{abstract}

Keywords: Leadership, Organizational Culture, Motivation, Employee Performance

\begin{abstract}
ABSTRAK : Penelitian ini dilaksanakan di Dinas Sumber Daya Air, Cipta Karya dan Tata Ruang Provinsi Sumatera Utara. Populasi dalam penelitian ini adalah seluruh karyawan di tiap divisi yang berjumlah 187 orang dengan Sampel yang di ambil hanya 65 orang, penentuan pengambilan Sampel dengan menggunakan Random Sampling. Instrumen atau teknik pengambilan data dalam penelitian ini menggunakan multiple choice yang telah di uji tingakat validitas dan realibilitas nya. uji asumsi klasik yang terdiri dari uji normalitas, multikolienaritas dan heterokedesitas dan Pengujian hipotesis menggunakan analisis regresi linier berganda, uji $F$ dan uji t. Dari hasil uji validitas diperoleh $r_{\text {hitung }}>r_{\text {tabel }}$ untuk masing-masing item pertanyaan dan uji reliabilitas angket diperoleh alpha cronbach masing-masing variabel yaitu 0,822 untuk variabel $X_{1}, 0,864$ untuk variabel $X_{2}, 0,859$ untuk variabel $X_{3}$ dan 0,922 untuk variabel $Y$. Nilai ini lebih besar dari taraf signifikan rtabel yaitu 0,361. Analisis data masing-masing variabel diperoleh persamaan regresi berganda $Y=15,086+0,400 X 1+0,326 X 2+0,936 X 3+e$. Diperoleh $R^{2}$ sebesar 0,517, yang berarti $X_{1}, X_{2}$ dan $X_{3}$ menjelaskan pengaruh terhadap variabel $Y$ sebesar $51,7 \%$ sedangkan sisanya $48,3 \%$ dijelaskan variabel lain diluar penelitian. Uji parsial yang dihasilkan masing-masing variabel bebas berpengaruh terhadap variabel terikat dengan signifikansi penelitian lebih kecil dari 0,05, serta hasil perhitungan uji-simultan sebesar 10,707 dengan $F_{\text {tabel }}$ 3,150 yang artinya $F_{\text {hitung }}>F_{\text {tabel }}$ dengan level of significant $(\alpha)$ 0,000 <0,05, yang artinya hipotesis diterima yaitu Kepemimpinan, Budaya Organisasi dan Motivasi Terhadap Kinerja Pegawai pada Dinas Sumber Daya Air, Cipta Karya dan Tata Ruang Provinsi Sumatera Utara.
\end{abstract}

Kata Kunci : Kepemimpinan, Budaya Organisasi, Motivasi, Kinerja Pegawai 


\section{Pendahuluan}

Sumber daya manusia merupakan faktor yang mutlak diperlukan dalam suatu organisasi, baik pada instansi pemerintah, perusahaan, atau pada usaha -usaha sosial dimana ia mendapatkan suatu balas jasa atau imbalan tertentu. Perkembangan dunia usaha akan terealisasi apabila ditunjang oleh sumber daya manusia yang berkualitas.

Setiap instansi dituntut meningkatkan kualitas Sumber Daya Manusia sehingga dapat bekerja secara produktif dan profesional serta kinerja yang dicapainya diharapkan akan lebih memuaskan dan sesuai standar kerja yang dipersyaratkan oleh instansi itu sendiri. Salah satu hal yang diperlukan dalam mencapai kinerja yang memuaskan adalah kemampuan profesional.

Kinerja pegawai adalah salah satu faktor utama yang mempengaruhi kemajuan instansi, sehingga semakin tinggi atau semakin baik kinerja pegawai maka tujuan instansi akan semakin mudah dicapai. Cara yang dapat diterapkan untuk meningkatkan kinerja pegawai adalah dengan menerapkan kepemimpinan yang efektif kepada pegawai. Diharapkan pemimpin dapat bersikap demokratis kepada pegawai serta pemimpin dapat menerapkan budaya perusahaan yang disepakati dengan pelatihan kerja serta motivasi yang diberikan oleh pemimpin terhadap pegawainya.

Keberhasilan sebuah instansi sangat bergantung kepada baik dan buruknya kinerja dari instansi. Kinerja dari instansi digambarkan oleh kinerja pegawai. Kinerja yang baik dari pegawai berdampak langsung kepada kemajuan atau kemunduran yang diperoleh instansi tersebut. Kinerja pegawai dapat dilihat dari kemampuan pegawai dalam melaksanakan keseluruhan tugas-tugas yang menjadi tanggung jawabnya.

Negara-negara di berbagai belahan dunia sedang menghadapi sebuah pandemic yaitu COVID-19 atau yang dikenal dengan sebutan virus corona. Dengan adanya virus ini kegiatan dikantor dibatasi dengan adanya kebijakan WFH (Work From Home) dan WFO (Work From Office). Dengan adanya kebijakan ini menurut informasi yang didapatkan beberapa pegawai tidak maksimal dalam bekerja karena kurangnya pengawasan dari atasan. Kurangnya pengawasan pemimpin dalam setiap pekerjaan sehingga pegawai merasa kurang mampu menjalani tugasnya dan tanggungjawabnya yang mengakibatkan kinerja pegawai menurun.
Faktor yang mempengaruhi kinerja pegawai salah satunya adalah dengan menumbuhkan motivasi kerja di kalangan pegawai. Motivasi adalah suatu pendorong bagi pegawai untuk mau bekerja dengan giat dan sungguh-sungguh untuk mencapai tujuan yang diinginkan. Motivasi timbul dengan adanya beberapa kebutuhan yang tidak terpenuhi sehingga menimbulkan tekanan atau rasa ketidakpuasan tersendiri sehingga mendorong terciptanya kinerja pegawai yang baik.

Namun yang terjadi di dinas berbeda. Beberapa pegawai tidak mampu menyelesaikan tugas yang diberikan dan pegawai juga mengeluhkan beban tugas tersebut, perilaku tersebut dapat disebabkan dengan kurangnya motivasi dalam lingkungan kerja. Untuk itu pegawai haruslah mendapatkan motivasi lebih dari pemimpin agar tidak menurunnya kinerja pegawai.

Budaya organisasi mempunyai pengaruh terhadap kinerja pegawai, karena budaya organisasi merupakan sistem nilai organisasi yang dianut oleh anggota organisasi yang kemudian mempengaruhi cara bekerja dan berperilaku dari para anggota oraganisasi.

Budaya organisasi juga menuntun kesamaan langkah dan visi bagi sumber daya manusia untuk melakukan tugas dan tanggung jawabnya, sehingga masing-masing individu dapat meningkatkan fungsinya didalam organisasi. Salah satunya dengan paham akan visi dan misi di dalam instansi, pegawai akan lebih termotivasi untuk meningkatkan kinerjanya demi terciptanya tujuan instansi tersebut.

Dinas Sumber Daya Air, Cipta Karya dan Tata Ruang Provinsi Sumatera Utara yang beralamat di Jalan Sakti Lubis No.7 Medan yang dipimpin oleh Alfi Syahriza, ST. M.Eng Sc, (2019 s/d Sekarang). Dinas Sumber Daya Air, Cipta Karya dan Tata Ruang Provinsi Sumatera Utara memilki 4 (empat) bidang dan 1 (satu) sekretariat, yaitu:

1) Sekretariat

2) Bidang Pengembangan Jaringan Pemanfaatan Air (PJPA)

3) Bidang Pengembangan Jaringan Sumber Air (PJSA)

4) Bidang Tata Ruang

5) Bidang Cipta Karya

Visi :

Terwujudnya Pendayagunaan Sumber Daya Air Yang Efisien, Efektif dan Bewawaan 
Lingkungan Untuk Masyarakat

Pemakai/Pengguna Air Di Provinsi Sumatera Utara.

\section{Misi :}

Untuk mewujudkan visi tersebut, perlu diselenggarakan Misi Pembamgunan pada Dinas Pengairan Provinsi Sumatera Utara sebagai berikut :

1) Mempertahankan dan memelihara keberadaan sifat dan fungsi sumber daya air untuk menjamin ketersediaan kuantitas dan kualitas air sebagai pengguna / pemakai air di Sumatera Utara.

2) Melaksanakan pengelolaan (konservasi, pendayagunaan dan pengendalian daya rusak air) sumber daya air untuk memenuhi kebutuhan berbagai sector seperti pertanian, domesti, perkotaan, industri, kelistrikan, parawisata dan lain-lain yang berwawasan lingkungan melalui perencanaan pelestarian sumber daya air.

3) Mengurangi dan menanggulangi resiko akibat bencana banjir, kekeringan, abrasi pantai dan kerusakan lain akibat atau dampak dari daya rusak air yang menimpa daeah produks pertanian, pemukiman, industri, prasarana fisik dan lain-lain.

4) Pemberdayaan peran serta masyarakat untuk ikut dalam pengelolaan sumber daya air khusus yang berkaitan dengan irigasi untuk dapat meningkatkan efisiensi dan efektifitas dalam pembangunan sumber daya air.

5) Menyusun dan melengkapi Sistem Data Base, Standar, Pedoman dan Manual pengelolaan sumber daya air untuk bahan dasar perencanaan pembangunan sarana dan prasarana sumber daya air serta penggunaan/pengalokasian sumber daya air agar tidak melebihi daya dukung sumber daya air itu sendiri.

6) Melaksanakan pengawasan, penyuluhan dan pembinaan pengelolaan sumber daya air kepada masyarakat untuk menjadi mitra kerja dalam rangka pelestarian sumber daya air.

Namun yang terjadi di dinas berbeda. Berdasarkan hasil wawancara, diperoleh informasi bahwa masih ada pegawai yang tidak memahami jelas akan visi dan misi. Hal ini menunjukkan bahwa kurangnya pengetahuan pegawai terhadap budaya organisasi yang ada di dalam Pemerintahan Provinsi Sumatera Utara khususnya di Dinas Sumber Daya Air, Cipta
Karya dan Tata Ruang Provinsi Sumatera Utara dan ini akan mengakibatkan terganggu berjalannya tujuan di Instansi terkait.

Cara yang dapat diterapkan untuk meningkatkan kinerja pegawai adalah dengan menerapkan kepemimpinan yang efektif kepada pegawai. Diharapkan pemimpin dapat bersikap demokratis kepada pegawai serta pemimpin dapat menerapkan budaya perusahaan yang disepakati dan motivasi yang mendukung serta pelatihan kerja yang diberikan para pegawainya.

Selain itu dengan adanya kepemimpinan, budaya organisasi, serta motivasi yang sesuai dengan pegawai maka hubungan antara pegawai dan pihak perusahaan akan dapat terjalin dengan baik. Sehingga pegawai sendiri akan berusaha untuk meningkatkan prestasi kerja sehingga terciptalah kinerja pegawai yang baik.

\subsection{Rumusan Masalah}

Berdasarkan pembatasan masalah diatas, batasan permasalahan dalam penelitian ini dapat dirumuskan sebagai berikut :

1) Apakah ada pengaruh kepemimpinan terhadap kinerja pegawai pada Dinas Sumber Daya Air, Cipta Karya dan Tata Ruang Provinsi Sumatera Utara?

2) Apakah ada pengaruh budaya organisasi terhadap kinerja pegawai pada Dinas Sumber Daya Air, Cipta Karya dan Tata Ruang Provinsi Sumatera Utara?

3) Apakah ada pengaruh motivasi terhadap kinerja pegawai pada Dinas Sumber Daya Air, Cipta Karya dan Tata Ruang Provinsi Sumatera Utara?

4) Apakah ada pengaruh kepemimpinan, budaya organisasi dan motivasi, terhadap kinerja pegawai pada Dinas Sumber Daya Air, Cipta Karya dan Tata Ruang Provinsi Sumatera Utara?

\subsection{Batasan Masalah}

Untuk menghindari kesimpang siuran dalam penelitian ini serta mengingat keterbatasan dan kemampuan penulis, maka penelitian ini dibatasi ruang lingkup masalah agar dapat diperoleh hasil yang diharapkan. Adapun yang menjadi batasan masalah dalam penelitian ini adalah "Pengaruh Kepemimpinan, Budaya Organisasi, dan Motivasi terhadap Kinerja Pegawai pada Dinas Sumber Daya Air, Cipta Karya dan Tata Ruang Provinsi Sumatera Utara." 


\subsection{Hipotesis}

Berdasarkan rumusan masalah dan kerangka pemikiran yang telah dijelaskan maka hipotesis dalam penelitian ini adalah :

1. Terdapat pengaruh kepemimpinan terhadap kinerja karyawan pada Dinas Sumber Daya Air, Cipta Karya dan Tata Ruang Provinsi Sumatera Utara.

2. Terdapat pengaruh budaya organisasi terhadap kinerja karyawan pada Dinas Sumber Daya Air, Cipta Karya dan Tata Ruang Provinsi Sumatera Utara.

3. Terdapat pengaruh motivasi terhadap kinerja karyawan pada Dinas Sumber Daya Air, Cipta Karya dan Tata Ruang Provinsi Sumatera Utara.

4. Terdapat pengaruh kepemimpinan, budaya organisasi dan motivasi terhadap kinerja karyawan pada Dinas Sumber Daya Air, Cipta Karya dan Tata Ruang Provinsi Sumatera Utara.

\subsection{Tujuan Penelitian}

Penelitian ini dilakukan dengan tujuan untuk mengetahui dan dapat menjelaskan bagaimana pengaruh kepemimpinan, budaya organisasi, dan motivasi terhadap kinerja pegawai pada Dinas Sumber Daya Air, Cipta Karya dan Tata Ruang Provinsi Sumatera Utara.

\section{Metode Penelitian}

\subsection{Populasi}

Menurut Sugiyono (2008:115) Populasi adalah wilayah generalisasi yang terdiri dari subjek atau objek yang mempunyai kualitas atau karakteristik tertentu yang ditetapkan oleh peneliti yang dipelajari dan kemudian ditarik kesimpulan.

Adapun yang menjadi populasi dalam penelitian ini adalah seluruh pegawai Dinas Sumber Daya Air, Cipta Karya dan Tata Ruang Provinsi Sumatera Utara di Jalan Sakti Lubis No. 7 Medan yang berjumlah 187 orang.

Tabel 1. Daftar Jumlah Pegawai

\begin{tabular}{|l|c|}
\hline \multicolumn{1}{|c|}{ Bagian / Divisi } & Jumlah \\
\hline Sekretariat & 57 orang \\
\hline Pengembangan Jaringan Pemanfaatan Air (PJPA) & 38 orang \\
\hline Pengembangan Jaringan Sumber Air (PJSA) & 32 orang \\
\hline Tata Ruang & 27 orang \\
\hline Cipta Karya & 33 orang \\
\hline Total & 187 orang \\
\hline
\end{tabular}

\subsection{Sampel}

Sampel adalah bagian dari jumlah dan karakteristik yang dimiliki oleh populasi. Pada penelitian ini peneliti tidak mengambil seluruh populasi sebagai sampel, karena jumlahnya yang besar yaitu sebesar 187 orang. Untuk menentukan jumlah sampel yang akan diambil digunakan rumus Slovin dengan tingkat kesalahan 10\% (Umar, 2002:78).

Rumus Slovin:

$$
n=\frac{N}{1+N(e)^{2}}
$$

Keterangan:

$$
\begin{array}{ll}
\mathrm{n} & =\text { Jumlah sampel } \\
\mathrm{N} & =\text { Ukuran populasi } \\
\mathrm{e} & =\text { Tingkat kesalahan }
\end{array}
$$

Berdasarkan rumus diatas dapat diketahui jumlah sampel dengan cara:

$$
\begin{aligned}
& n=\frac{187}{1+187(0,1)^{2}} \\
& n=\frac{187}{1+1,87}=65,15(\text { dibulatkan menjadi }
\end{aligned}
$$

65 orang )

Tabel 2. Jumlah Sampel Masing - Masing Divisi

\begin{tabular}{|c|l|c|c|}
\hline No & \multicolumn{1}{|c|}{ Divisi / Bagian } & Populasi & Sampel \\
\hline 1. & Sekretariat & 57 & 19 \\
\hline 2. & Pengembangan Jaringan Pemanfaatan Air (PJPA) & 38 & 13 \\
\hline 3. & Pengembangan Jaringan Sumber Air (PJSA) & 32 & 12 \\
\hline 4. & Tata Ruang & 27 & 10 \\
\hline 5. & Cipta Karya Total karyawan & 33 & 11 \\
\hline \multicolumn{2}{|c|}{ Trang } \\
\hline
\end{tabular}


Maka jumlah sampel yang akan diambil berjumlah 65 orang untuk memudahkan penulis dalam pengolahan data. Teknik pengambilan sampel menggunakan random sampling.

\subsection{Uji Normalitas}

Tujuan dari uji normalitas adalah untuk mengetahui apakah dalam model regresi variabel dependent dan variabel independent memiliki distribusi normal atau tidak. Model regresi yang baik adalah yang memiliki distribusi data normal atau mendekati normal.

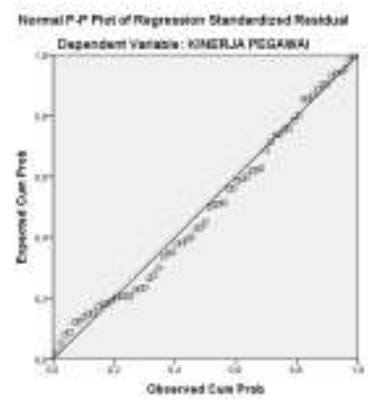

Gambar 1. Normal P.P Plot Of Regression Standardized Residual

Gambar Normal P.P Plot Of Regression Standardized Residual di atas menunjukan titik yang menyebar disekitar diagonal dan penyebaranya mengikuti arah garis diagonal sehingga dapat disimpulkan bahwa data modal regresi berdistribusi normal.

\subsection{Uji Multikolinearitas}

Untuk medeteksi apakah model regresi yang dipakai bebas dari permasalahan Multikolinearitas dapat dilihat dari :

A. Besar VIF ( Variance Inflation Factor ) dan toleransi, dimana VIF lebih kecil dari 10 ( VIF < 10) dan nilai toleransi lebih besar dari 0,1 ( tolerance $>0,1$ ).

Tabel 3. Coefficients

Coefficients $^{\mathrm{a}}$

\begin{tabular}{|c|c|c|c|c|c|c|c|}
\hline \multirow[t]{2}{*}{ Model } & \multicolumn{2}{|c|}{$\begin{array}{l}\text { Unstandardized } \\
\text { Coefficients }\end{array}$} & \multirow{2}{*}{$\begin{array}{c}\begin{array}{c}\text { Standardized } \\
\text { Coefficients }\end{array} \\
\text { Beta }\end{array}$} & \multirow[t]{2}{*}{$\mathrm{t}$} & \multirow[t]{2}{*}{ Sig. } & \multicolumn{2}{|c|}{$\begin{array}{l}\text { Collinearity } \\
\text { Statistics }\end{array}$} \\
\hline & B & Std. Error & & & & Tolerance & VIF \\
\hline (Constant) & 15,086 & 6,506 & & 2,319 &, 124 & & \\
\hline $\begin{array}{l}\text { KEPEMIMPIN } \\
\text { AN }\end{array}$ & ,400 & 699 & ,218 & 3,573 & ,009 & ,889 & 1,287 \\
\hline $\begin{array}{l}\text { BUDAYA } \\
\text { ORGANISASI }\end{array}$ & ,326 & ,280 & ,216 & 2,807 & ,006 & 899 & 1,287 \\
\hline MOTIVASI & ,938 & 654 & ,554 & 3,434 & ,007 & 886 & 1,287 \\
\hline
\end{tabular}

Dari tabel coefficients di atas dapat dilihat nilai toleransi untuk kepemimpinan $\left(\mathrm{X}_{1}\right)$ budaya organisasi $\left(\mathrm{X}_{2}\right)$ dan motivasi $\left(\mathrm{X}_{3}\right)=0,889$. Sedangkan VIF untuk kepemimpinan $\left(\mathrm{X}_{1}\right)$ budaya organisasi $\left(\mathrm{X}_{2}\right)$ dan motivasi $\left(\mathrm{X}_{3}\right)=$ 1,287. Hal ini menunjukan bahwa VIF lebih kecil dari 10 dan nilai toleransi lebih besar dari 0,1 yang berarti tidak terjadi masalah multikolinearitas pada model regresi.

B. Nilai ${ }^{\mathrm{R}}$ yang menunjukan nilai yang lebih kecil dari koefisien korelasi simultan ( $\mathrm{R}$ ).

Tabel 4. R square

Model Summary ${ }^{b}$

\begin{tabular}{|l|c|r|r|r|}
\hline $\begin{array}{l}\text { Mod } \\
\text { el }\end{array}$ & $\mathrm{R}$ & $\begin{array}{c}\mathrm{R} \\
\text { Square }\end{array}$ & $\begin{array}{c}\text { Adjusted R } \\
\text { Square }\end{array}$ & $\begin{array}{c}\text { Std. Error } \\
\text { of the } \\
\text { Estimate }\end{array}$ \\
\hline 1 &, $766^{\mathrm{a}}$ &, 517 &, 579 & 2,965489 \\
\hline
\end{tabular}

a. Predictors: (Constant), MOTIVASI, BUDAYA

ORGANISASI, KEPEMIMPINAN

b. Dependent Variable: KINERJA PEGAWAI

Pada tabel data output diatas diperoleh nilai

$\mathrm{R}=0,766$ dan nilai $\mathrm{R}^{2}=0,517$. Hal ini 
menunjukan bahwa $\mathrm{R}^{2}<\mathrm{R}$ yang berarti tidak terdapat permasalahan multikolinearitas dalam model regresi yang digunakan.

Dari kedua alat pengujian di atas dapat disimpulkan bahwa secara umum tidak terdapat multikolinearitas pada model regresi yang akan digunakan.

\subsection{Uji Heterekodesitas}

Pengujian terhadap Heterekodesitas dapat dilakukan melalui pengamatan terhadap pola scatter plot yang dihasilkan melalui SPSS. Suatu model regresi linier berganda dapat dikatakan bebas dari permasalahan heterkodesitas jika :

- Titik-titik data menyebar di atas dan dibawah atau disekitar angka nol ( 0 )

- Titik-titik data tidak mengumpul hanya di atas atau dibawah saja

- Penyebaran titik-titik data tidak boleh membentuk pola bergelombang, melebar, kemudian menyempit dan melebar lagi

- Penyebaran titik-titik data sebaiknya tidak berpola.

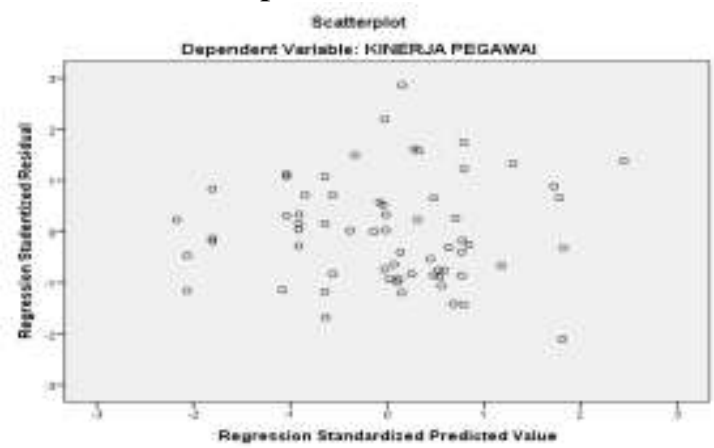

Gambar 2. Scatterplot Regresi Standar Residual
Pada gambar diatas menunjukan bahwa titiktitik data menyebar di sekitar angka nol, dan tidak mengumpul disatu titik. Penyebaran titiktitik data tersebut juga tidak membentuk suatu pola. Jadi dapat disimpulkan bahwa model regresi penelitian ini tidak mengalami permasalahan heterokedesitas.

\section{Analisa dan Pembahasan}

\subsection{Analisis Regresi Berganda}

Model Regresi Berganda dengan satu variabel dependent $(\mathrm{Y})$ yaitu Kinerja Pegawai dan 3 variabel Independent (X1) yaitu Kepemimpinan, (X2) yaitu Budaya Organisasi, dan (X3) yaitu Motivasi yaitu dirumuskan sebagai berikut.

$$
\mathbf{Y}=\mathbf{a}+\mathbf{b}_{1} \mathbf{x}_{1}+\mathbf{b}_{2} \mathbf{x}_{2+} \mathrm{e}
$$

Untuk menguji hipotesis yang menyatakan terdapat pengaruh Kepemimpinan (X1), Budaya Organisasi (X2), dan Motivasi (X3) terhadap Kinerja Pegawai $(\mathrm{Y})$ digunakan alaisis regresi berganda. Berdasarkan hasil perhitungan diperoleh hasil persamaan regresi berganda sebagai berikut :

Tabel 5. Hasil Perhitungan Regresi Linier Berganda

Coefficients $^{\text {a }}$

\begin{tabular}{|c|c|c|c|c|c|c|c|c|}
\hline \multirow{2}{*}{\multicolumn{2}{|c|}{ Model }} & \multicolumn{2}{|c|}{$\begin{array}{l}\text { Unstandardized } \\
\text { Coefficients }\end{array}$} & \multirow{2}{*}{$\begin{array}{c}\text { Standardized } \\
\text { Coefficients }\end{array}$} & \multirow[t]{2}{*}{$\mathrm{t}$} & \multirow[t]{2}{*}{ Sig. } & \multicolumn{2}{|c|}{$\begin{array}{l}\text { Collinearity } \\
\text { Statistics }\end{array}$} \\
\hline & & B & Std. Error & & & & $\begin{array}{c}\text { Toleran } \\
\text { ce }\end{array}$ & VIF \\
\hline \multirow{4}{*}{1} & (Constant) & 15,086 & 6,506 & & 2,319 &, 124 & & \\
\hline & $\begin{array}{l}\text { KEPEMIMPI } \\
\text { NAN }\end{array}$ & ,400 & ,699 & ,218 & 3,573 & ,009 & 889, & 1,287 \\
\hline & $\begin{array}{l}\text { BUDAYA } \\
\text { ORGANISASI }\end{array}$ &, 326 & 280, & ,216 & 2,807 & ,006 & 899, & 1,287 \\
\hline & MOTIVASI & ,938 & 654 &, 554 & 3,434 & ,007 & ,886 & 1,287 \\
\hline
\end{tabular}

a. Dependent Variable: KINERJA PEGAWAI 
Dari hasil SPSS diatas dapat dijelaskan sebagai berikut :

$$
Y=7,396+0,429 x_{1}+0,378 x_{2}+e
$$

- Konstanta sebesar 15,086 menyatakan bahwa jika tidak ada variabel $\mathrm{X}$, yaitu Pelatihan Kerja dan Pemberian Insentif maka Kinerja Karyawan adalah sebesar 15,086, dengan asumsi faktor lain konstan.

- Koefisien X1 sebesar 0,400 , menyatakan bahwa setiap terjadi kenaikan Kepemimpinan akan mempengaruhi Kinerja Pegawai sebesar $0,400 \quad(40,0 \%)$ dengan asumsi faktor lain konstan.

- Koefisien X2 sebessar 0,326, menyatakan bahwa setiap terjadi peningkatan Budaya Organisasi akan mempengaruhi Kinerja
Pegawai sebesar 0,326 (32,6\%) dengan asumsi faktor lain konstan.

- Koefisien X3 sebessar 0,938, menyatakan bahwa setiap terjadi peningkatan Budaya Organisasi akan mempengaruhi Kinerja Pegawai sebesar $0,938 \quad(93,8 \%)$ dengan asumsi faktor lain konstan.

\subsection{Uji Hipotesis}

\subsubsection{Pengujian Hipotesis Secara Parsial Menggunakan Uji T}

Uji t dilakukan untuk mengetahui pengaruh Kepemimpinan, Budaya Organisasi, dan Motivasi secara parsial atau individu terhadap Kinerja Pegawai. Adapun hasil uji t dalam penelitian ini adalah sebagai berikut :

Tabel 6. Uji t

Coefficients $^{\mathrm{a}}$

\begin{tabular}{|c|c|c|c|c|c|c|c|c|}
\hline \multirow{2}{*}{\multicolumn{2}{|c|}{ Model }} & \multicolumn{2}{|c|}{$\begin{array}{c}\text { Unstandardized } \\
\text { Coefficients }\end{array}$} & \multirow{2}{*}{$\begin{array}{c}\begin{array}{l}\text { Standardized } \\
\text { Coefficients }\end{array} \\
\text { Beta } \\
\end{array}$} & \multirow[t]{2}{*}{$\mathrm{t}$} & \multirow[t]{2}{*}{ Sig. } & \multicolumn{2}{|c|}{$\begin{array}{l}\text { Collinearity } \\
\text { Statistics }\end{array}$} \\
\hline & & $\mathrm{B}$ & Std. Error & & & & Tolerance & VIF \\
\hline \multirow{4}{*}{1} & (Constant) & 15,086 & 6,506 & & 2,319 &, 124 & & \\
\hline & KEPEMIMPINAN & 400 & 699 & ,218 & 3,573 & ,009 & ,889 & 1,287 \\
\hline & $\begin{array}{l}\text { BUDAYA } \\
\text { ORGANISASI }\end{array}$ & ,326 & ,280 & , 216 & 2,807 & ,006 & 899 & 1,287 \\
\hline & MOTIVASI & ,938 & ,654 & ,554 & 3,434 & 007 & 886 & 1,287 \\
\hline
\end{tabular}

Dari tabel di atas maka dapat dijelaskan bahwa :

1) Nilai $t$ hitung variabel Kepemimpinan $3.573>$ dari $t$ tabel yaitu 1,669 dan nilai signifikan $0.000<0,05$ Hal ini berarti hipotesis diterima yaitu : Kepemimpinan secara parsial berpengaruh positif dan signifikan terhadap Kinerja Pegawai Dinas Sumber Daya Air, Cipta Karya dan Tata Ruang Provinsi Sumatera Utara.

2) Nilai t hitung variabel Budaya Organisasi 2,807> dari $t$ tabel yaitu 1.669 dan nilai signifikan $0.000<0,05$. Hal ini berarti hipotesis diterima yaitu : Budaya Organisasi secara parsial berpengaruh positif dan signifikan terhadap Kinerja Pegawai Dinas Sumber Daya Air, Cipta Karya dan Tata Ruang Provinsi Sumatera Utara.

3) Nilai t hitung variabel Motivasi 3,434> dari t tabel yaitu 1.669 dan nilai signifikan $0.000<$ 0,05 . Hal ini berarti hipotesis diterima yaitu :
Motivasi secara parsial berpengaruh positif dan signifikan terhadap Kinerja Pegawai Dinas Sumber Daya Air, Cipta Karya dan Tata Ruang Provinsi Sumatera Utara.

4) Menentukan $T$ tabel dapat dilihat pada tabel statistic pada signifikansi $0,05 / 2=0,025$ dengan derajat kebebasan $\mathrm{df}=\mathrm{n}-3$ atau $65-$ $3=62$, dan hasil yang diperoleh dari $\mathrm{T}$ tabel sebesar 1,669 ( Di lihat pada lampiran $\mathrm{T}$ tabel )

\subsubsection{Pengujian Hipotesis Secara Simultan Menggunakan Uji F}

Uji Simultan atau Uji F merupakan Uji secara bersama-sama untuk menguji signifikan pengaruh variabel Kepemimpinaan, Budaya Organisasi dan Motivasi terhadap Kinerja Pegawai.

Berdasarkan hasil pengujian statistik (Uji Anova/Uji F) Dapat dilihat pada tabel output berikut: 
Tabel 7. Uji F

ANOVA $^{\mathrm{a}}$

\begin{tabular}{|c|c|c|c|c|c|c|}
\hline \multicolumn{2}{|c|}{ Model } & $\begin{array}{l}\text { Sum of } \\
\text { Squares }\end{array}$ & $\overline{\mathrm{df}}$ & Mean Square & $\mathrm{F}$ & Sig. \\
\hline \multirow{3}{*}{1} & Regression & 1075,788 & 3 & \multirow{3}{*}{$\begin{array}{r}358,596 \\
63,449\end{array}$} & \multirow[t]{3}{*}{5,652} & \multirow[t]{3}{*}{, $002^{b}$} \\
\hline & Residual & 3870,390 & 61 & & & \\
\hline & Total & 4946,178 & 64 & & & \\
\hline
\end{tabular}

a. Dependent Variable: KINERJA PEGAWAI

b. Predictors: (Constant), MOTIVASI, BUDAYA ORGANISASI, KEPEMIMPINAN

Pada tabel diatas diperoleh bahwa nilai $\mathrm{F}=$ 5,652 dengan tingkat signifikansi $0,000<0,05$. $\mathrm{F}$ tabel dapat dilihat pada table statistik (Terlampir) pada tingkat signifikansi 0,05 dengan df 3 (Jumlah variabel-1) $=2$, dan df 3 (n- k-1) atau $64-3-1=60$ Setelah mengetahui $\mathrm{F}$ hitung, maka akan di bandingkan dengan $\mathrm{F}$ table dengan taraf kesalahan $5 \%$ adalah $=3,150$ maka $F$ hitung $=5,652>F$ table $(3,150)$. Dengan demikian , dapat ditarik kesimpulan koefisien arah regresi berganda pada taraf signifikan 0.05 yang artinya Kepemimpinan, Budaya Organisasi dan
Motivasi secara bersama-sama berpengaruh positif dan signifikan terhadap Kinerja Pegawai Dinas Sumber Daya Air, Cipta Karya dan Tata Ruang Provinsi Sumatera Utara.

\subsubsection{Koefisien Determinasi ( R Square )}

Untuk mengetahui seberapa besar Persentase Pengaruh variabel bebas terhadap variabel terikat atau untuk melihat seberapa besar variabel bebas dapat menjelaskan pengaruhnya terhadap variabel terikat. Maka dilakukan pengujian koefisien determinasi $\left(\mathrm{R}^{2}\right)$ sehingga di peroleh hasil seperti tabel di bawah ini. Tabel 8. Hasil Uji $\mathrm{R}^{2}$

Model Summary ${ }^{\mathrm{b}}$

\begin{tabular}{l|c|r|r|c|}
\hline $\begin{array}{l}\text { Mod } \\
\text { el }\end{array}$ & $\mathrm{R}$ & $\begin{array}{c}\mathrm{R} \\
\text { Square }\end{array}$ & $\begin{array}{c}\text { Adjusted R } \\
\text { Square }\end{array}$ & $\begin{array}{l}\text { Std. Error of } \\
\text { the Estimate }\end{array}$ \\
\hline 1 &, $766^{\mathrm{a}}$ &, 517 &, 579 & 2,965489 \\
\hline
\end{tabular}
a. Predictors: (Constant), MOTIVASI, BUDAYA ORGANISASI,
KEPEMIMPINAN
b. Dependent Variable: KINERJA PEGAWAI

Dari tabel output diatas dapat dilihat bahwa koefisien determinan $\left(\mathrm{r}^{2}\right)$ adalah sebesar 0,517. Nilai ini menunjukan bahwa variabel Kinerja Pegawai (Y) dipengaruhi oleh variabel Kepemimpinan (X1), Budaya Organisasi (X2), dan Motivasi (X3) secara bersama-sama sebesar $51,7 \%$ dan sisanya $48,3 \%$ dipengaruhi oleh Variabel lain yang tidak dibahas dalam penelitian ini.

\section{Evaluasi Data}

\subsection{Pembahasan Hasil Penelitian}

Penelitian ini bertujuan untuk mengetahui dan menganalisis pengaruh Kepemimpinan, Budaya Organisasi dan Motivasi terhadap Dinas Sumber Daya Air, Cipta Karya dan Tata Ruang Provinsi Sumatera Utara. Penelitian ini dilakukan dengan menggunakan metode analisis Regresi Berganda dan metode statisitik, pada metode Analisis berganda diperoleh informasi dari responden melalui kuesioner yang berisikan tentang karakteristik responden yaitu jenis kelamin dan usia atas pernyataan dalam kuesioner. Sedangkan pada metode statistik pengolahan data dilakukan dengan program SPSS 22.

Berdasarkan hasil penelitian bahwa nilai $\mathrm{R}^{2}$ sebesar 0,517 yang berarti variabel Kepemimpinan, Budaya Organisasi dan Motivasi memberikan pengaruh terhadap Variabel Kinerja Pegawai sebesar 51,7\%, Sedangkan sisanya 48,3\% dijelaskan oleh faktor lain diluar dari Variabel penelitian ini.

Jika ditinjau dari pengaruh secara parsial (Uji t), variabel Kepemimpinan berpengaruh secara positif dan signifikan terhadap Kinerja Pegawai Dinas Sumber Daya Air, Cipta Karya dan Tata Ruang Provinsi Sumatera Utara, hal ini terlihat dari nilai signifikan 3.573>dari $\mathrm{t}_{\text {tabel }}$ yaitu 1,669 dan nilai signifikan $0.000<0,05$. 
Variabel Budaya Organisasi secara parsial berpengaruh secara positif dan signifikan terhadap Kinerja Pegawai Dinas Sumber Daya Air, Cipta Karya dan Tata Ruang Provinsi Sumatera Utara, hal ini terlihat dari nilai signifikan Insentif 2,807> dari t tabel yaitu 1.669 dan nilai signifikan $0.000<0,05$.

Variabel Motivasi secara parsial berpengaruh secara positif dan signifikan terhadap Kinerja Pegawai Dinas Sumber Daya Air, Cipta Karya dan Tata Ruang Provinsi Sumatera Utara, hal ini terlihat dari nilai signifikan Insentif 3,434> dari $\mathrm{t}$ tabel yaitu 1.669 dan nilai signifikan $0.000<0,05$.

Dari hasil penelitian juga membuktikan Hipotesis diterima dengan adanya hasil secara simultan (uji F) yaitu F hitung = 5,652 > F tabel ( 3,150$)$, dengan demikian dapat ditarik kesimpulan koefisien arah regresi berganda pada taraf signifikan 0,05 yang artinya kepemimpinan, budaya organisasi, dan motivasi berpengaruh positif dan signifikan terhadap kinerja pegawai di Dinas Sumber Daya Air, Cipta Karya dan Tata Ruang Provinsi Sumatera Utara.

\section{Kesimpulan}

Hasil dari penelitian ini dapat disimpulkan sebagai berikut :

1) Setelah penulis melakukan penelitian mengenai pengaruh Kepemimpinan, Budaya Organisasi dan Motivasi terhadap Kinerja Pegawai pada Dinas Sumber Daya Air, Cipta Karya dan Tata Ruang Provinsi Sumatera Utara, maka dapat disimpulkan bahwa secara parsial Kepemimpinan berpengaruh positif dan signifikan terhadap Kinerja Pegawai Dinas Sumber Daya Air, Cipta Karya dan Tata Ruang Provinsi Sumatera Utara. Hal ini menyatakan hipotesis yang dirumuskan penulis yaitu "Kepemimpinan secara parsial berpengaruh terhadap Kinerja Pegawai Dinas Sumber Daya Air, Cipta Karya dan Tata Ruang Provinsi Sumatera Utara" telah diuji dan terbukti dapat diterima kebenarannya.

2) Selanjutnya Budaya Organisasi secara parsial menyatakan ada pengaruh yang positif dan signifikan terhadap Kinerja Pegawai Dinas Sumber Daya Air, Cipta Karya dan Tata Ruang Provinsi Sumatera Utara. Hal ini menyatakan hipotesis yang dirumuskan penulis yaitu "Budaya Organisasi secara parsial berpengaruh terhadap Kinerja Pegawai Dinas Sumber
Daya Air, Cipta Karya dan Tata Ruang Provinsi Sumatera Utara" telah di uji dan terbukti dapat diterima kebenarannya.

3) Dan yang terakhir Motivasi secara parsial menyatakan ada pengaruh yang positif dan signifikan terhadap Kinerja Pegawai Dinas Sumber Daya Air, Cipta Karya dan Tata Ruang Provinsi Sumatera Utara. Hal ini menyatakan hipotesis yang dirumuskan penulis yaitu "Motivasi secara parsial berpengaruh terhadap Kinerja Pegawai Dinas Sumber Daya Air, Cipta Karya dan Tata Ruang Provinsi Sumatera Utara" telah di uji dan terbukti dapat diterima kebenarannya.

\section{DAFTAR PUSTAKA}

Agustini, Fauzia. 2011. Manajemen Sumber Daya Manusia Lanjutan, Madenatera, Medan.

Amirullah dan Haris Budiono. 2004. Pengantar Manajemen, Cetakan Kedua, Graha Ilmu, Yokyakarta.

Bernardin dan Russel. 2010. Manajemen Sumber Daya Manusia. Diterjemahkan oleh : Bambang Sukoco, PT. Amico, Bandung.

Davis, Keith dan Newstrom. 2000. Perilaku Dalam Organisasi Edisi Ketujuh, Erlangga, Jakarta.

Dessler, Gary. 2007. Manajemen Sumber Daya Manusia, Indeks, Jakarta.

Febriansyah, Hardino. 2012. Analisis Pengaruh Kepemimpinan, Motivasi dan Lingkungan Kerja Terhadap Kinerja Pegawai Badan Diklat Provinsi Jawa Tengah. Skripsi. Universitas Diponegoro Semarang.

Ghozali, Imam. (2009). Aplikas iAnalisis Multivariate dengan Program SPSS. Semarang:

BadanPenerbitUniversitasDiponegoro.

Handoko. 2007. Sumber Manajemen Personalia dan Daya Manusia, Edisi Kedua, BPFEYogyakarta, Yogyakarta.

Harimisa, Margareta E. 2013. Kepemimpinan dan Motivasi Kerja Pengaruhnya terhadap Produktivitas Kerja Pegawai di Kantor Camat Sario Kota Manado. Jurnal EMBA. ISSN 2303-1174.Vol:1. No:4. Desember 2013.Hal. 2143-2154.

Hasibuan, Malayu S.P. 2011. Manajemen Sumber Daya Manusia. Edisi Revisi, Bumi Aksara, Jakarta. .2009. Manajemen Sumber Daya Manusia, PT. Bumi Aksara, Jakarta. 
2005. Manajemen Sumber Daya Manusia, Bumi Aksara, Yokyakarta.

Juliandi, Azuar. (2013). Metode Penelitian Kuantitatif untuk Ilmu-Ilmu Bisnis. Medan: M2000.

Kartini, Kartono. 2003. Pemimpin dan Kepemimpinan, PT. Remaja Rosda Karya, Bandung.

Kreitner, Robbert. 2005. Perilaku Organisasi, Gramedia Pustaka Utama, Jakarta.

Kuntjaraningrat. 2004. Teori organisasi. Alfabeta, Bandung.

Lubis, Khairul Akhir. 2008. Pengaruh Pelatihan dan Motivasi Kerja Terhadap Kinerja Karyawan PT. Perkebunan Nusantara IV (Persero) Medan. Tesis. Universitas Sumatera Utara.

Luthans, Fred. 2005. Perilaku Organisasi, Edisi Sepuluh, Diterjemahkan oleh : Vivin Andhika Yuwono, Penerbit Andi, Jakarta.

Mahsun, Mohammad. 2006. Pengukuran Kinerja Sektor Publik, BPFE Yogyakarta, Yogyakarta.

Mangkunegara, Prabu Anwar. 2005. Perilaku dan Budaya Organisasi, PT. Refika Aditama, Bandung. 2001. Evaluasi kinerja manajemen, PT. Refika Aditama, Bandung.

Maramis, Enrico. 2013. Kepemimpinan, Budaya Organisasi, dan Motivasi Pengaruhnya terhadap Kinerja Karyawan pada PT. Bank Tabungan Negara (Persero) Cabang Manado. Jurnal EMBA. ISSN 23031174.Vol:1. No:4.Desember 2013.Hal:955963.

Moeheriono. 2009. Pengukuran Kinerja Berbasis Kompetensi, Ghalia Indonesia, Jakarta.

Ruky, Ahmad, 2004. Sistem Manajemen Kinerja. Penerbit PT. Gramedia Pustaka Utama, Jakarta.

Robbins, P. Stephen. 2006. Perilaku Organisasi, Indeks, Jakarta.

Santoso, Joko. 2009. Teori-Teori Kepemimpinan, Sebelas Maret University Press, Sukarta.

Sastrohadiwiryo, Siswanto 2005.Manajemen Tenaga Kerja Indonesia. PT. Bumi Aksara, Jakarta.

Sedarmayanti. 2007. Manajemen Sumber Daya Manusia, Refika Aditama, Bandung.
Schein, Edgar H. 2004. Organizational Culture and Leadership, Third Edition, Jossey-Bass Publishers, San Francisco.

Siagian, Sondang. 2002. Manajemen Sumber Daya Manusia, Bumi Aksara, Jakarta.

Simanjuntak, Payaman J. 2011. Manajemen dan Evaluasi Kinerja, Edisi Ketiga, Lembaga Penerbit FEUI, Jakarta.

Situmorang, (2012).Analisis Data untuk Riset Manajemen dan Bisnis, Edisi kedua USU Press, Medan.

Soedjono. 2005. Pengaruh Budaya Organisasi Terhadap Kinerja Organisasi dan Kepuasan Kerja Karyawan pada Terminal Penumpang Umum di Surabaya. Jurnal Manajemen dan Kewirausahaan. Vol: 1. No. 7. Hal:22-47.

Sugiono. 2008. Metode Penelitian Bisnis (Pendekatan Kuantitatif, Kualitatif, dan $R$ \& $D)$, Alfabeta, Bandung.

Suparno Sudarwati. 2014. Pengaruh Motivasi, Disiplin Kerja dan kompetensi terhadap Kinerja Pegawai Dinas Pendidikan Kabupaten Sragen. Jurnal Paradigma. ISSN :1693-0827. Vol:12. No:1. Februari - Juli 2014. Hal:12.

Sutrisno, Edy. 2007. Budaya Organisasi, Kencana, Jakarta. 2009. Manajemen Sumber Daya Manusia, Edisi Pertama, Cetakan Pertama, Kencana, Jakarta.

Tampubolon, Manahan. 2004. Perilaku Keorganisasian, Edisi Pertama, Ghalia Indonesia, Jakarta.

Tika, P. 2006. Budaya Organisasi dan Peningkatan Kinerja Perusahaan, PT. Bumi Aksara, Jakarta.

Trang, Dewi Sandy. 2013). Gaya Kepemimpinan dan Budaya Organisasi pengaruhnya terhadap Kinerja Karyawan. Jurnal EMBA. ISSN 2303-1174. Vol:1. No:3. September 2013. Hal:208-216.

Umar, Husein. 2005. Riset Sumber Daya Manusia Dalam Organisasi, Di PT. Gramedia Pustaka Utama, Jakarta. 2002. Metode Riset Bisnis, Gramedia, Jakarta.

Wibowo. 2009. Manajemen Kinerja, Edisi Ketiga, PT. Raja Grafindo Persada, Jakarta.

Wijayanto, Dian. 2012. Pengantar Manajemen, Penerbit PT. Gramedia Pustaka Utama, Jakarta.

Wirawan. 2007. Budaya dan Iklim Organisasi, Salemba Empat, Jakarta. 